\title{
Impacts of Northwest Fisheries Extension Project (NFEP) on pond fish farming in improving livelihood approach
}

\author{
M. R. Islam ${ }^{1}$ and M. R. Haque ${ }^{2}$ \\ ${ }^{1}$ Department of Fisheries Biology and Genetics, ${ }^{2}$ Department of Fisheries Management, Bangladesh Agricultural \\ University, Mymensingh-2202, Bangladesh
}

\begin{abstract}
Investigation was carried out from June to August 2009. A total of 40 fish farmers were selected from northwest two upazila namely Debigonj $(n=20)$ and Boda $(n=20)$ where both men and women were targeted. Focus group discussion (FGD) and cross-check interview were conducted to get an overview on carp farming. From 1991-1995, $1996-2000$ and after $2000 ; 17.5 \%, 45 \%$ and $37.5 \%$ of fish farmers started carp farming respectively. Average $77.5 \%$ of farmers acquired training from NFEP project while $10 \%$ of them from government officials. There were $55 \%$ seasonal and $45 \%$ perennial ponds with average pond size 0.09 ha. After phase out of NFEP project, $92.5 \%$ of fish farmers followed polyculture systems, while only $7.5 \%$ of them followed monoculture ones. Farmers did not use any lime, organic and inorganic fertilizers in their ponds before association with NFEP project. They used lime, cow dung, urea and T.S.P during pond preparation at the rate of $247,2562.68,46.36$ and $27.29 \mathrm{~kg} \cdot \mathrm{ha}^{-1} . \mathrm{y}^{-1}$ respectively where stocking density at the rate of 10,775 fry.ha ${ }^{-1}$ after phase out of the project. Feeding was at the rate of $3-5 \%$ body

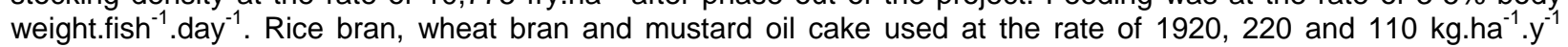
respectively by $85 \%$ of fish farmers but $15 \%$ of them did not used any feed. Before NFEP project, average pond production was $408.55 \mathrm{~kg} \cdot \mathrm{ha}^{-1}$ but after phase out the project, fish production was $2,861.08 \mathrm{~kg}^{-\mathrm{ha}^{-1}}$. Peak culture and harvesting period lied from April to December and from November to January. Average $92.5 \%$ of farmers improved their livelihood through carp farming. Fish farming was affected due to low water depth and drought conditions.
\end{abstract}

Keywords: NFEP, Fish farming parameters, Pond production, Livelihood approach

\section{Introduction}

The NFEP project evolved through collaboration between the British Department For International Development (DFID), Overseas Development Administration (ODA) and the Department of Fisheries (DoF) of the Government of Bangladesh (GoB). It is actual rural aquaculture support services started from January 1987. Since the project started, NFEP launched their aquaculture based programmed through three phases namely Phase-I, Phase-II and Phase-III or closing phase. The Phase-I worked across five administrative districts in the northwest region of Bangladesh (Panchagarh, Thakurgaon, Dinajpur, Rangpur, and Nilphamari) since 1987 and ended in 1994 as a model project. After successful completion of the Phase-I, NFEP entered its phase-II in the northwest eight administrative districts of Bangladesh (Dinajpur, Gaibandha, Lalmonirhat, Nilphamari, Panchagarh, Rangpur, Kurigram, and Thakurgaon) from 1996 and ended in 2001. The Phase-III started in 2001 and ended in 2007, worked in eleven administrative districts in the northwest of Bangladesh (Dinajpur, Gaibandha, Lalmonirhat, Nilphamari, Panchagar Rangpur, Kurigram, Thakurgaon, Nowgan, Jaipurhat and Bogra) transferring technology to the farmers by demonstration programs and trainings. Both men and women pond operators were targeted as groups who were interested in achieving higher aquaculture yields and sustainable income from their own or leased pond resources. These groups took small and marginal farming families and under employed young peoples where women as beneficiaries and staff of the project. The project office was centrally situated at the Parbatipur hatchery complex with twenty hectare site includes a modern farm, trial hatchery, library, laboratory and residential training facilities.

Aquaculture contributes to the livelihood of the poor farmers through improved food supply, employment and income (Edwards, 2000). It also contributes over $70 \%$ of the total aquaculture production in Bangladesh. Carp culture has been accepted as a powerful production option through reducing rural poverty, alleviating cases of malnutrition among children and mothers, empowering women and raising family living standards. Pond fish farmers are convinced that fish culture is a cash crop and has the potential for crop diversification and improved earnings. During nineteenth and early twentieth century, 
historical sources showed that between $85 \%$ and $95 \%$ of the Bengal populations were fish eaters (Ali, 1997). The rich and diverse nature of water environments provided the opportunities for pond fish culture in Bangladesh. However, governmental (GOs) and nongovernmental organizations (NGOs) have been trained and allocation resources for production oriented research by encouraging the rural people to increase fish production. In this view, we assessed the impacts of knowledge on carp farming hold by NFEP project in the northwest regions of Bangladesh.

\section{Materials and Methods}

This investigation was carried out for three months from June to August 2009. Northwest Fisheries Extension Project (NFEP) worked in about 87 upazilas in Dinajpur, Rangpur, Panchagar, Thakurgoan, Gaibanda, Kurigram and Nilphamary districts. Two upazilas of Panchagarh district namely Debigonj and Boda were selected for the study because a large number of pond fish farmers operating carp farming and its associated activities.

Considering these entire aspects, 40 fish farmers were selected for the present study of which 20 farmers from Debigonj upazila and another 20 farmers from Boda upazila. Participatory Rural Appraisal (PRA) is a group of methods to collect information from pond fish farmers in participatory fashion (Chambers, 1992). PRA tool like as focus group discussion (FGD) was conducted fish farmers to get an overview on carp farming technologies and the culturing constraints etc. A total of 8 FGD sessions (four in each upazila) were conducted where each group size of FGD was 4 to 6 . Cross-check interviews were conducted with key informants such as upazila fisheries officers, school teachers, local leaders, service holders both private and government and relevant GOs and NGOs officers and staffs. Data collected from various sources were coded and entered into a data base system using "Microsoft Excel Software" and "SPSS" (Statistical package for social science) computer package. At each stage of survey, data sheets were compared with original data to ensure the accuracy of data entered.

\section{Results and Discussion}

\section{Background of fish farming practice}

Before the involvement with NFEP project, fish culture in ponds or other water bodies was not taken and almost all people's in the northwestern areas caught fish from natural water bodies. When fish abundance and availability decreased day by day in nature, the rich people in these area's felt extra fish stocking (Indigenous species) in their ponds and other derilict ponds. They also thought to take carp farming in their ponds. A total of 40 interviewed farmers from which $0 \%$ of fish farmers started carp farming before 1990, 17.5\% from 1991-1995, 45\% from 1996-2000 and 37.5\% after 2000 through NFEP project (Fig. 1). The highest percentage (50\%) of fish farmers started carp farming from 1996-2000 in Boda upazila than Debigonj (40\%) upazila. Almost all interviewed farmers stated that the primary reasons for carp farming were money earnings and also believed carp farming to be more profitable and cheap than crop productions. Most of the farmers started that carp farming in the study area under the supervision of NFEP project and all of them were benefited through economically and technically. Rahman (2003) also found that 44\% of fish farmers started carp farming from 1991-1995 in Gazipur district.

\section{Training on fish farming}

From NFEP project, $77.5 \%$ of fish farmers received technical knowledge on fish culture whereas $0 \%$ from NGOs, $12.50 \%$ from self-study and $10 \%$ of them procured from government staffs. Highest percentage $(80 \%)$ of fish farmers achieved training experiences from NFEP in Debigonj upazila than Boda (75\%). Most of the fish farmers in Debigonj upazila were in better condition due to present more ponds than the farmers of Boda upazila (Fig. 2). Besides this, fish demand was very high and increasing regularly in Debigonj upazila than another, which inspired the farmers to involve carp farming and training activities more. Now, there were no active training activities in that areas which affected fish productions and fish farmers motivated into alternative activities mainly agricultural activities. However, Rahman (2003) found that $43 \%$ of farmers obtained experience from MAEP in Gazipur district. So, NFEP project was more effective means to transfer technologies into fish farmers which resulted in more aquaculture productions. 

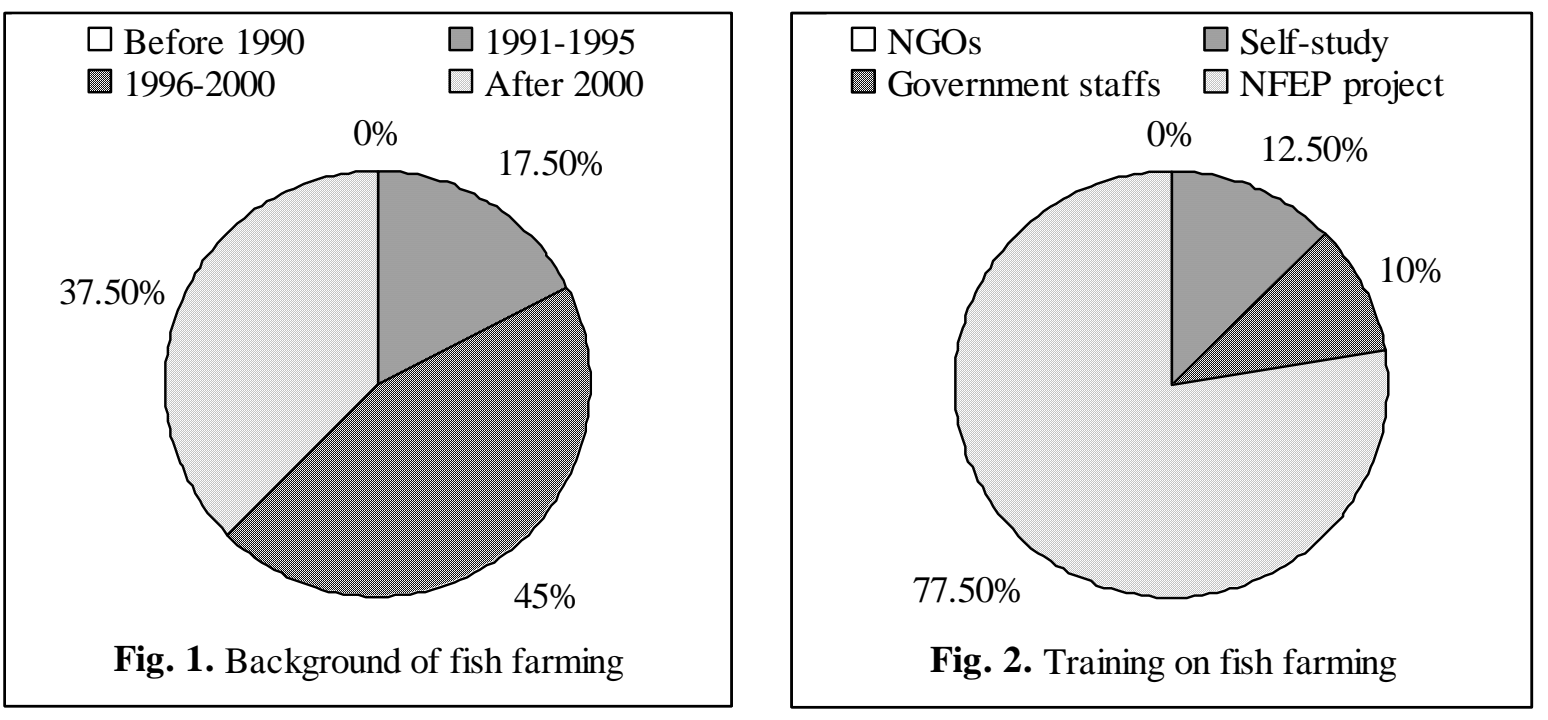

\section{Pond type and pond size}

Water retention capacity of soil is another factor in the northwestern region of Bangladesh where 55\% of ponds were seasonal and $45 \%$ of them were perennial. Seasonal ponds become also totally unsuitable for fish culture during dry season in Debigonj upazila than Boda due to low water retention capacities of sandy soil (Table 1). However, before involvement with NFEP project the average pond size was 0.09 ha (22.23 decimal), after involvement the pond size was 0.118 ha (29.15 decimal) and after phase out the average pond size 0.174 ha (42.98 decimal) respectively (Table 3). Rahman (2003) found that average pond size was 0.12 ha in Dinajpur sadar upazila. Saha (2004) found that $37 \%$ of ponds were seasonal and $63 \%$ of them were perennial in Tangail sadar upazila which were more or less similar to the northwestern region of Bangladesh. Saha (2003) also observed that $17 \%$ of ponds were seasonal and $83 \%$ of them were perennial in Dinajpur sadar upazila. Saha et al. (1995) found that the range of pond size were within 0.05 to 0.15 ha in Bangladesh. The reason for higher number of small ponds in the northwestern region of Bangladesh might be due to the fragmentation of land and the economic inability of the pond owners resulting loss of aquatic habitat resources. On the other hand, small ponds have operational facilities than larger ones.

Table 1. Seasonal and perennial ponds in the northwestern region of Bangladesh

\begin{tabular}{|l|c|c|c|}
\hline \multirow{2}{*}{ Type of ponds } & Debigonj upazila & Boda upazila & Total \\
\cline { 2 - 4 } & $\mathrm{n}=20$ & $\mathrm{n}=20$ & $\mathrm{~N}=40$ \\
\hline Seasonal & $15(75 \%)$ & $7(35 \%)$ & $22(55 \%)$ \\
\hline Perennial & $5(25 \%)$ & $13(65 \%)$ & $18(45 \%)$ \\
\hline
\end{tabular}

\section{Sources of fry and culture method}

Before involvement with NFEP project, farmers stocked fry from local fry traders. After involvement with NFEP project, farmers stoked nursery produced fry and after phase out the project, farmer's also stocked nursery produced fry from hatcheries to confirm good quality fish seeds for increased fish production. After engaged with NFEP project, $92.5 \%$ of the farmers followed polyculture systems to get more fish productions by stocking Indian major carps and exotic carps while $7.5 \%$ of them took monoculture (Table 3). Farmers stocked Indian major carps viz., catla, (Catla catla), rohu (Labeo rohita), mrigal (Cirrhinus cirrhous), and Exotic carps, viz., comon carp (Cyprinus carpio), silver carp (Hypophthalmichthys molitrix) and grass carp (Ctenopharyngodon idella). However, Hossain et al. (1992) found that $74 \%$ of the ponds were stocked with only Indian major carps while $19 \%$ of them were stocked with Indian major carps and exotic carps together. This result was not similar to the above because farmers had a tendency to get frequently more production from the same pond at a time. 


\section{Liming and fertilization}

Before involvement with NFEP project, farmers did not use lime in the pond. When involved with the NFEP project, farmers used lime at the rate of $177 \mathrm{~kg} \cdot \mathrm{ha}^{-1} \cdot \mathrm{y}^{-1}$ and after the phase out the project they used lime at the rate of $247 \mathrm{~kg} \cdot \mathrm{ha}^{-1} \cdot \mathrm{y}^{-1}$ to get more fish productions. Before NFEP project, farmers did not use any organic and inorganic fertilizers during pond preparation. When engaged they used organic and inorganic fertilizers such as cow dung, urea, T.S.P. at the rate of $2146.75,35.33$ and $20.96 \mathrm{~kg}^{-h^{-1}} \cdot \mathrm{y}^{-1}$ respectively. After phase out of the NFEP project, they also used cow dung, urea and T.S.P. at the rate of $2562.68,46.36$ and $27.29 \mathrm{~kg} \cdot \mathrm{ha}^{-1} \cdot \mathrm{y}^{-1}$ respectively. On the other hands, before NFEP project, they also not used any fertilizer in their pond during the culture periods. After involvement, farmers used cow dung, urea and T.S.P. at the rate of $5.0,24.7$ and $12.35 \mathrm{~kg}_{\text {.decimal }}{ }^{-1} .10^{-1}$ days respectively. After phase the project, they also used same doses of organic and inorganic fertilizer during fish culture which knowledge gathered from NFEP project (Table 3). Hassanuuzaman (1997) observed in Rajshahi district that the average doses of organic fertilizer was $2,801 \mathrm{~kg} \cdot \mathrm{ha}^{-1} \cdot \mathrm{y}^{-1}$ and inorganic fertilizer was $97 \mathrm{~kg} \cdot \mathrm{ha}^{-1} \cdot \mathrm{y}^{-1}$. Saha at al. (1995) also found that the average doses organic and inorganic fertilizers were 15,210 and $432 \mathrm{~kg}$.ha 1. However, Rana (1996) found in his study in Sirajgonj district that use of organic fertilizer was 8,122 $\mathrm{kg} \cdot \mathrm{ha}^{-1} \cdot \mathrm{y}^{-1}$ and inorganic fertilizer was $315 \mathrm{~kg} \cdot \mathrm{ha}^{-1} \cdot \mathrm{y}^{-1}$ with the optimum rate of using organic fertilizer was $24,700 \mathrm{~kg} \cdot \mathrm{ha}^{-1} \cdot \mathrm{y}^{-1}$.

\section{Stocking density of fish fry}

Prior to the NFEP project, farmers stocked fish seed at the rate of 38,038 fry.ha ${ }^{-1}$. When procured with NFEP project, stocking density of fish seed were reduced at 14,832 fry.ha $^{-1}$. After phase out of the project, stocking density was gradually reached at the rate of 10,775 fry.ha ${ }^{-1}$ (Table 3). These were occurred due to lack of fish culture knowledge and farmers always thought the higher stocking densities, the higher fish production. But this misunderstanding caught when they were engaged with NFEP project in the northwestern region. Hassanuzzaman (1997) found the average density of carp at the rate of $16,196 \mathrm{ha}^{-1} \cdot \mathrm{y}^{-1}$ in Rajshahi district and NFEP-II (1998) suggested that the stocking density of carps was optimum at the rate of 14,820 fry.ha ${ }^{-1}$. Hossain at al. (1992) found that the stocking density of carps varied from 10,000 to 31,000 fry.ha ${ }^{-1}$ in the pond fisheries of Mymensingh district.

\section{Feed and feeding}

Before involvement with NFEP project, farmers did not use any type of feeds to feed fish. During association and the phase out of NFEP project, they used rice bran, wheat bran and mustard oil cake at the rate of 1920,220 and $100-110 \mathrm{~kg} \cdot \mathrm{ha}^{-1} \cdot \mathrm{y}^{-1}$ respectively. Feeding found at the rate of $5 \%$ body weight daily during 1-2 months initially while $3 \%$ body weight up to harvest of fish. For fish farming, $85 \%$ of fish farmers used feed, while $15 \%$ of fish farmers did not use any feed in their. Rahman et al. (1998) found that rice bran was supplied at the rate of $2745 \mathrm{~kg} \cdot \mathrm{ha}^{-1}$. Saha et al. (1995) found that higher rate of rice bran was $5192 \mathrm{~kg} \cdot \mathrm{ha}^{-1}$.

\section{Culture and harvesting season}

The culture season of fish farming lied from April to December. Available carp fries were stocked from April to May and the peak harvesting season lied from November to January. Ahmed (2003) observed that peak period of carp polyculture was April to December. Saha (2004) reported that the peak harvesting season was from November to January. Rahman (2003) observed that the peak harvesting period observed from October to January, which was similar to the present study. Rahman (2003) also reported that the season of carp farming was hold from March to December. The culture periods were varied due to seed supply, seed price, rainy season and aim of farmers but harvesting time varied due to market demands, market supply and economic condition of farmers. More sandy soil recorded in Debigonj upazila which led to later culture initiations but early fish harvesting than Boda upazila which hampered the fish farmer's economically. 


\section{Harvesting type and marketing system}

Study showed that $87.5 \%$ of farmers followed partial harvesting and restocking technique of fish while $12.5 \%$ of them harvested fully because of reducing water depth. Farmer's harvested their cultured fish by using cast net and seine net locally known as Ber jal, usually netting several times at a week. Harvested fish were then kept in aluminum containers or bamboo baskets. Around $72.5 \%$ of farmers sold their captured fish to the fish traders, whereas $17.5 \%$ of them sold the fish to the retailers (foria) and the rest $10 \%$ of them to the fish agent. Ahmed (2003) stated that the peak harvesting season lied from December to March where harvesting was done using cast net and seine net in Gazipur district. Fish farmers of two upazilas used cast net and seine net to catch cultured fish because these gears were cheap, easily available and manageable. Partial harvesting would help small fish to become larger but farmers in both upazilas did not know about this benefit when they were not involved with NFEP project.

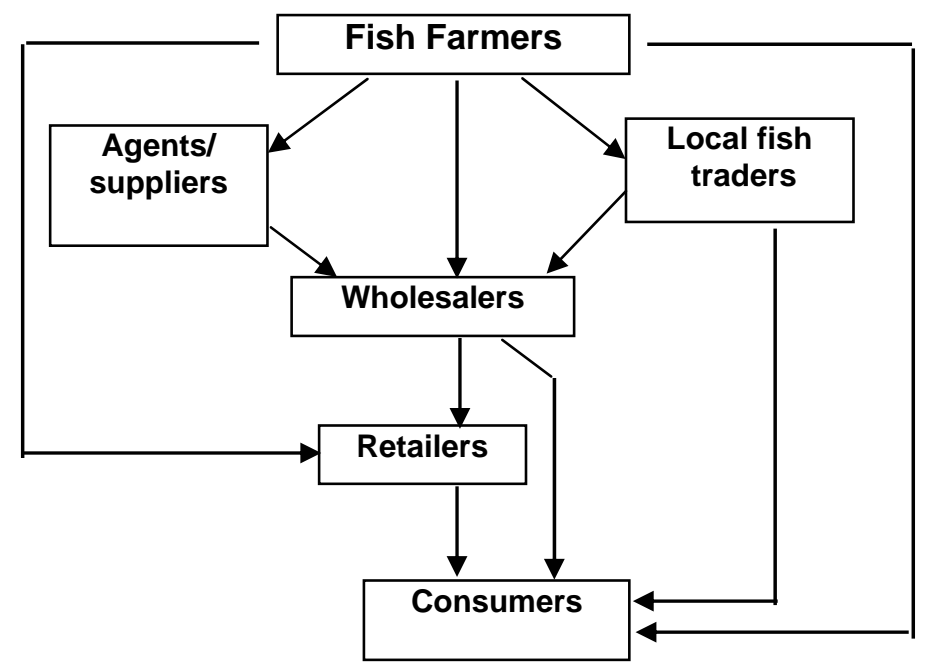

Fig. 3. Marketing channel of fishes

\section{Fish production}

Prior to NFEP project, the farmer's average fish production were $408.55 \mathrm{~kg} \cdot \mathrm{ha}^{-1}$. After involvement farmer's average fish production were $2,224.07 \mathrm{~kg} \cdot \mathrm{ha}^{-1}$ and when phase out average fish productions were 2,861.08 kg.ha-1 (Table 3). Biswas (2001) stated that the average yield was 3,734 kg.ha ${ }^{-1}$ which was higher than the present study. Hassanuzzaman (1997) in Rajshashi district found that the average fish production was $1,242 \mathrm{~kg} \cdot \mathrm{ha}^{-1}$. From the above, fish production was being increased because of the involvements with NFEP project and when farmers followed the NFEP culture techniques like stocking density, species ratio, rate of feed and fertilizer etc.

\section{Improved livelihood approach}

Average $92.5 \%$ of farmers improved their socio-economic conditions through carp farming because they practiced aquaculture according to the instructions of NFEP project (Table 2). Such improvements may be described as increased food consumption, increased social status, and broadly improved their standards of living, purchasing power, choice and ability as an economic sector. Some of $(7.5 \%)$ farmers not obtained any specific benefits from their involvement in carp farming due to some undesirable circumstances such as lack of technical knowledge, drought and loaning pressure. Ahmed (2002) also found that $71 \%$ prawn farmers improved their socio-economic condition through prawn production. 
Table 2. Improvement livelihood approach through fish farming

\begin{tabular}{|l|c|r|r|}
\hline \multirow{2}{*}{ Improvement livelihood approach } & Debigonj upazila & Boda upazila & Total \\
\cline { 2 - 4 } & $\mathrm{n}=20$ & $\mathrm{n}=20$ & $\mathrm{~N}=40$ \\
\hline Yes & $17(85 \%)$ & $14(70 \%)$ & $31(77.5 \%)$ \\
\hline No & $3(15 \%)$ & $6(30 \%)$ & $9(22.5 \%)$ \\
\hline
\end{tabular}

Table 3. Pond size (ha), culture type, doses of lime (kg.ha-1. $\left.\cdot y^{-1}\right)$, stocking density (fry.ha ${ }^{-1}$ ), doses of organic and inorganic fertilizer and yield $\left(\mathrm{kg} \mathrm{ha}^{-1} \cdot \mathrm{y}^{-1}\right)$ in the northwestern region of Bangladesh

\begin{tabular}{|c|c|c|c|c|c|c|c|c|c|}
\hline \multirow[b]{2}{*}{$\begin{array}{l}\text { Culture } \\
\text { parameters }\end{array}$} & \multicolumn{3}{|c|}{ Debigonj upazila $(n=20)$} & \multicolumn{3}{|c|}{ Boda upazila $(n=20)$} & \multicolumn{3}{|c|}{ Total $(\mathrm{N}=40)$} \\
\hline & $\begin{array}{c}\text { Before } \\
\text { involvement } \\
\text { with NFEP } \\
\text { project }\end{array}$ & $\begin{array}{c}\text { After } \\
\text { involvement } \\
\text { with NFEP } \\
\text { project }\end{array}$ & $\begin{array}{c}\text { After phase } \\
\text { out of NFEP } \\
\text { project }\end{array}$ & $\begin{array}{c}\text { Before } \\
\text { involvement } \\
\text { with NFEP } \\
\text { project }\end{array}$ & $\begin{array}{c}\text { After } \\
\text { involvement } \\
\text { with NFEP } \\
\text { project }\end{array}$ & $\begin{array}{l}\text { After phase } \\
\text { out of NFEP } \\
\text { project }\end{array}$ & $\begin{array}{c}\text { Before } \\
\text { involvement } \\
\text { with NFEP } \\
\text { project }\end{array}$ & $\begin{array}{c}\text { After } \\
\text { involvement } \\
\text { with NFEP } \\
\text { project }\end{array}$ & $\begin{array}{l}\text { After phase } \\
\text { out of NFEP } \\
\text { project }\end{array}$ \\
\hline Pond size & 0.076 & 0.110 & 0.169 & 0.105 & 0.126 & 0.179 & 0.09 & 0.118 & 0.174 \\
\hline Monoculture & $89 \%$ & $39 \%$ & $7 \%$ & $91 \%$ & $41 \%$ & $8 \%$ & $90 \%$ & $40 \%$ & $7.5 \%$ \\
\hline Polyculture & $11 \%$ & $61 \%$ & $93 \%$ & $9 \%$ & $59 \%$ & $92 \%$ & $10 \%$ & $60 \%$ & $92.5 \%$ \\
\hline Dose of lime & - & 167 & 239 & - & 187 & 255 & - & 177 & 247 \\
\hline Stocking density & 36920 & 15326 & 11450 & 39155 & 14320 & 10101 & 38038 & 14823 & 10775 \\
\hline Cow dung & - & 2138.88 & 2517 & - & 2154.62 & 2608.35 & - & 2146.75 & 2562.68 \\
\hline Poultry manure & - & - & - & - & - & - & - & - & - \\
\hline Compost & - & - & - & - & - & - & - & - & - \\
\hline Urea & - & 31.84 & 45.84 & - & 38.82 & 46.88 & - & 35.33 & 46.36 \\
\hline T.S.P & - & 19.7 & 27.71 & 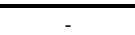 & 22.25 & 26.87 & - & 20.96 & 27.29 \\
\hline M.P & - & - & - & - & - & - & - & - & - \\
\hline Average yield & 388.56 & 2158.58 & 2823.32 & 428.54 & 2289.57 & 2898.85 & 408.55 & 2224.07 & 2861.08 \\
\hline
\end{tabular}

$\mathrm{N}=$ Sample size; $\mathrm{N}=$ Total sample size

\section{Constraints of fish farming}

Fish farming has a positive impact on aquaculture production but numerous types of constraints affect potentiality of fish farming in the northwestern region of Bangladesh. Very poor water retention capacity of soil, low water flow from upstream river, lack of loan facilities, low quality and scarcity of fish seeds in proper time were the main barrier of fish farming in the study areas. Due to seasonal ponds, most of them have converted their ponds into crop's fields. Ali and Rahman (1986) stated that a sandy soil of the ponds was a major problem with $19 \%$ of the fish pond owners in Lalmonirhat district who stated that this problem mainly occurred due to Farakka Barrage of India. Besides this, average $37.5 \%$ of farmers were identified lack of money, $30 \%$ of higher production cost, $17.5 \%$ of low quality seeds and lack of technical assistants. Rhaman (2003) stated that the major constraints of carp farming were lack of money and production cost. Khan et al. (1998) also identified that the lack of knowledge about fish culture was one of the most important problems. Hossain et al. (1992) observed that the largest problems faced by fish farmers are multiple ownerships.

Carp production is a profitable business through which carp farmers would improve his life styles. Now, aquaculture production has increased but not yet fulfilled the daily requirements of the country resulting in higher market price. As a result, poor people can not take the test of fishes and suffer from malnutrition. Besides this, scientific trainings on carp farming, involvement of government and NGOs to ensure farmer's credits and loan facilities with low or no interests could increase the aquaculture production dramatically. In Bangladesh, about $70 \%$ of the country's people are lived in rural areas of which $50 \%$ live in poverty and more than one in fives live in extreme poverty (FAO, 1999). After phase out of NFEP project, most of the farmers maintained scientific fish culture technology, which acquired through NFEP project and improved their socio-economic conditions. But fish farming can contribute to eliminate the poverty and poor livelihood approaches of fish farmers which would promote the national economics of Bangladesh. 


\section{Acknowledgements}

The authors are thankful to the fish farmers in Boda and Debigonj upazila under the northern district of Panchagarh who participated in the study and NFEP project to take such type of developing program in fish production in northern region of Bangladesh.

\section{References}

Ahamed, F. 2003. Comparative study on carp poly culture practices of three different NGOs in Mymensingh district. M.S. dissertation. Department of Aquaculture, BAU, Mymensingh. 65 p.

Ali, M. and Tsou, C.S. 1997. Combating micronutrient deficiencies through vegetables-a neglected food frontier in Asia. Food Policy., 22: 17-38.

Biswas, S.S. 2001. An economic analysis of pond fish culture of BRAC in some selected areas of Mymensingh district. M.S. dissertation. Department of Agricultural Economics, BAU, Mymensingh. 80 p.

Chambers, R. 1992. Rapid appraisal: rapid, relaxed and participatory. Discussion paper no. 13, Institute of development Studies, University of Sussex, Brighton. $212 \mathrm{p}$.

Edwards, P. 2000. Aquaculture, poverty impacts and livelihoods, natural resources perspective, ODI. No. 56 June 2000.

FAO. 1999. FAOSTAT '98. FAO statistical databases. CD-ROM. FAO Production Yearbook. Rome, Italy: FAO.

Hassanuzzaman, A.K.M. 1997. Comparative study on pond fish production under different management systems in some selected areas of Rajshahi district. M.S. dissertation. Department of Agricultural production Economics, BAU, Mymensingh. 76 p.

Hossain, M.S., Dewan, S., Islam, M.S. and Hossain, S.M.A. 1992. Survey of pond fishery resources in a village of Mymensingh district. Bangladesh J. Aqua., 14-16:33-37.

Khan, A.N.M.I., Rahman, M.M. and Islam, M.A. 1998. Factors causing difficulty in pond fish culture in a selected area of Mymensingh district. Bangladesh J. Aqua., 20:23-27.

NFEP-II. 1998. Aquaculture manual for literate and semi-literate farmers. North-West Fisheries Extension Project-2, Parabatipur, Dinajpur. $81 \mathrm{p}$.

Rahman, M.A., Sofiquuzzoha, M.Z. and Nurullah, M. 1998. Efficiency of pond fish production in Bangladesh, Bangladesh J. Agril. Sci., 25(2): 235-239.

Rahman, M.M. 2003. Socio-economic aspects of carp culture development in Gazipur, Bangladesh. M.S. dissertation Department of Agricultural Economic., BAU, Mymensingh. 83 p.

Rahman, M.M. 2003. Socio-economic aspects of carp culture development in Gazipur, Bangladesh. M.S. dissertation. Department of Fisheries Management, BAU, Mymensingh. 72 p.

Rana, M.S. 1996. An economics analysis of pond fish culture in some selected areas of Sirajganj district. M.S. dissertation. Department of Agricultural Economics, BAU, Mymensingh. 83 p.

Saha, M.K. 2003. A study on Fish Production Technology in North-West Bangladesh. M.S. dissertation. Department of Aquaculture, BAU, Mymensingh. $71 \mathrm{p}$.

Saha, N.C., Islam, M.S., Saha, J.K. and Modak, P.C. 1995. Economics of pond fish production in some selected areas of Bangladesh, Bangladesh J. Aqua., 17: 13-18.

Saha, S.K. 2004. Socio-economic aspects of Aquaculture in Tangail Sadar Upazila, M.S. dissertation. Department of Aquaculture, BAU, Mymensingh. 77 p. 